\section{Income Inequality and Health}

Coastal Communities in British Columbia, Canada

\author{
Gerry Veenstra, PhD
}

\section{ABSTRACT}

Objective: An imbalance in the distribution of economic resources, i.e., income inequality, is a characteristic of a community that may influence the aggregate health of the population. In North America, income inequality seems to be strongly related to mortality rates among American communities such as states and metropolitan areas but largely irrelevant for health at similar levels of geopolitical aggregation in Canada. This article summarizes relevant international and North American evidence and then explores relationships between income inequality and mortality rates among coastal communities in the province of British Columbia, Canada.

Methods: Cross-sectional analysis was conducted among twenty-four coastal communities in British Columbia, utilizing four measures based on the 1996 Census to measure income inequality and crude, age-standardized and age- and gender-specific mortality rates averaged over the five-year period 1994-98 to measure health.

Results: The three valid measures of income inequality were positively and significantly related to the crude mortality rate but were not significantly related to the agestandardized mortality rate. Two of the inequality measures were related to mortality rates for males aged 0-44 and for males aged 45-64 before but not after controlling for mean household income.

Discussion: Health researchers have yet to report a meaningful relationship between income inequality and population health within Canada. At the risk of committing the ecological fallacy, these findings provisionally support a psycho-social interpretation of the individual-level relationship between income and health wherein members of these communities compare themselves to an encompassing community, e.g., all Canadians.

La traduction du résumé se trouve à la fin de l'article.

Department of Anthropology and Sociology, Centre for Health Services and Policy Research, University of British Columbia, Vancouver, BC

Correspondence and reprint requests: Gerry Veenstra, Dept. of Anthropology and Sociology, University of British Columbia, 6303 N. W. Marine Dr., Vancouver, BC V6T 1Z1, Tel: 604-822-4351, Fax: 604-822-6161, E-mail: veenstra@chspr.ubc.ca

Sources of support: Gerry Veenstra is supported by a New Investigator Award (2000-2005) from the Canadian Institutes of Health Research. The economic data for these communities were collected for the Resilient Communities Project, a project led by co-investigators Ralph Matthews, Brian Elliott and Gerry Veenstra at the University of British Columbia and funded by the Social Sciences and Humanities Research Council of Canada.
W ithin many, if not all, Western countries, income is related to various measures of health status, ${ }^{1-6}$ a finding that certainly applies to the United States ${ }^{7,8}$ and Canada. ${ }^{9-14}$ The relationship between income and health appears to be curvilinear: the average difference in health status between those near the bottom of the income ladder and those a few steps up is more pronounced than among steps nearer the top. ${ }^{15-17}$ Such inequalities in income and health represent an individual-level approach to economic determinants of health. Alternatively, income inequality can be conceptualized as a characteristic of a community or society that is relevant for the aggregate health of the entire population. One simple measure of income inequality is the proportion of total household income dollars held by the poorest $50 \%$ of households. More complex measures tend to focus on the Lorenz curve, i.e., they order the population by wealth, calculate the proportion of total wealth held by each proportion of the (ranked) populace and then assess the area under the curve.

Income inequality as a characteristic of a community is thought to affect the aggregate health of the entire populace via health-relevant attributes of communities potentially caused by and/or dialectically interrelated with inequality. Hypothesized attributes include an ungenerous welfare state, characterized by minimal investment in education, health and social services, affordable housing, roads or environmental protection; ${ }^{18}$ high rates of crime; ${ }^{19}$ intense social class or ethnic competition and discrimination; ${ }^{20}$ strong adherence to neoliberal doctrines; ${ }^{21}$ changing household compositions $^{22}$ and low levels of social cohesion or social capital. ${ }^{18,23-26}$ Explanations that focus on such ecological correlates locate the relationship between income inequality and health primarily in the realm of social, economic and political relations. Conversely, inequality-health relationships among communities may be generated by an individual-level relationship between income and health. Given the purported curvilinear nature of the relationship between income and health, we would expect to find a significant ecological relationship between income inequality and health. ${ }^{16,18,27}$ That is, if we collapsed the wealthy and the poor toward the middle of the income hierarchy in a 


\section{TABLE I}

\section{Income Inequality and Population Health: Ecological Relationships in North America}

\begin{tabular}{|c|c|c|c|c|}
\hline Author(s) & Context & Population Health & Income Inequality & Relationship \\
\hline Kawachi and Kennedy ${ }^{40}$ & American states $(n=50)$ & $\begin{array}{l}\text { Age-standardized } \\
\text { mortality }\end{array}$ & $\begin{array}{l}\text { Gini coefficient } \\
\text { Decile ratio } \\
\text { Median share } \\
60 \% \text { share } \\
70 \% \text { share } \\
\text { Robin Hood Index } \\
\text { Atkinson Index eta }=2 \\
\text { Atkinson Index eta=0.5 } \\
\text { Theil's Entropy Measure }\end{array}$ & $\begin{array}{l}r=0.51 \\
r=0.65 \\
r=-0.58 \\
r=-0.54 \\
r=-0.50 \\
r=0.54 \\
r=0.66 \\
r=0.56 \\
r=0.52 \\
\text { All significant after controlling for poverty } \\
\text { and median income. }\end{array}$ \\
\hline Daly et al. ${ }^{41}$ & American states $(n=50)$ & Age-adjusted mortality & $\begin{array}{l}\text { Median share } \\
\text { 90:10 ratio } \\
\text { 80:20 ratio } \\
\text { 90:50 ratio } \\
\text { 80:50 ratio } \\
\text { 50:10 ratio } \\
\text { 50:20 ratio }\end{array}$ & $\begin{array}{l}r=-0.62 \\
r=0.69 \\
r=0.66 \\
r=0.53 \\
r=0.56 \\
r=0.72 \\
r=0.67 \\
\text { All significant after controlling for median } \\
\text { income. }\end{array}$ \\
\hline Lynch et al. ${ }^{42}$ & $\begin{array}{l}\text { American metropolitan } \\
\text { areas }(n=282)\end{array}$ & Age-adjusted mortality & $\begin{array}{l}\text { Gini coefficient } \\
\text { Median share } \\
50: 10 \text { ratio } \\
\text { Atkinson Index eta=2 } \\
\text { Atkinson Index eta=0.5 } \\
90: 10 \text { ratio } \\
\text { Theil Entropy Index }\end{array}$ & $\begin{array}{l}r=0.25 \\
r=-0.33 \\
r=0.51 \\
r=0.40 \\
r=0.27 \\
r=0.52 \\
r=0.21 \\
\text { All significant after controlling for poverty } \\
\text { and per capita income. }\end{array}$ \\
\hline Wilson and Daly ${ }^{43}$ & $\begin{array}{l}\text { Neighbourhoods in } \\
\text { Chicago }(n=77)\end{array}$ & Life expectancy & Robin Hood Index & $\begin{array}{l}r=-0.75 \text { for males, } r=-0.68 \text { for females. } \\
\text { Significant after controlling for median } \\
\text { household income. }\end{array}$ \\
\hline Ross et al. ${ }^{44}$ & $\begin{array}{l}\text { Canadian metropolitan } \\
\text { areas }(n=53)\end{array}$ & All-age mortality & Median share & Not significant. \\
\hline Veenstra ${ }^{26}$ & $\begin{array}{l}\text { Health districts in } \\
\text { Saskatchewan }(n=30)\end{array}$ & $\begin{array}{l}\text { Age-standardized } \\
\text { mortality }\end{array}$ & Mean-median measure & Kendall's tau_b=0.24, $p=0.06$ \\
\hline
\end{tabular}

given community, the health of the poor would improve more than the health of the wealthy would decline, leaving the community less unequal and healthier in the aggregate. As such the ecological relationship may be a statistical artefact, empirically but not theoretically meaningful.

Is there evidence of ecological relationships between income inequality and health? Among nine Western nations of the Luxembourg Income Study, including the US and Canada, Wilkinson ${ }^{23}$ reported a strong relationship $(\mathrm{r}=0.86)$ between the proportion of overall wealth held by the poorest $70 \%$ of families and life expectancy. With an expanded data set of 16 Western nations, Lynch et al. ${ }^{28}$ noted strong and statistically significant relationships between the Gini coefficient (based on the Lorenz curve) and both infant $(r=0.69$ for females; $r=0.74$ for males) and youth ( $r=0.53$ for females; $r=0.60$ for males) mortality rates, after controlling for national wealth. Income inequality was not significantly related to all-age mortality, mortality in other age groups, life expectancy or aggregated self-rated health, however. Judge et al. ${ }^{16}$ surveyed 12 studies pertaining to between-nation comparisons and noted that most found some evidence of an ecological association between income inequality and some measure(s) of population health, ${ }^{29-36}$ but with exceptions $s^{16,37}$ and not always after controlling for other factors. ${ }^{38,39}$

Results from similar analyses in North America are summarized in Table I. Income inequality appears to have a strong relationship with mortality at the level of the state and a moderately strong relationship among metropolitan areas, suggesting that exploration at similar levels of geopolitical aggregation in Canada could be fruitful. This does not appear to be the case: analysis at the levels of the Canadian province, ${ }^{44}$ metropolitan area ${ }^{44}$ and health district in Saskatchewan ${ }^{26}$ produced (at best) only weak relationships. As such income inequality as an ecological characteristic of communities may be irrelevant for the health of Canadians, although strong relationships among neighbourhoods in one American study ${ }^{43}$ suggests that a lower level of aggregation may produce meaningful results in Canada. This article seeks to extend the scope of inquiry in Canada by exploring ecological relationships at a lower level of analysis than has yet been explored in that country - small communities on the coast of British Columbia.

There is empirical reason to argue the ecological relationships described among American communities are more than statistical artefacts. Wolfson et al..$^{15}$ produced mathematical models for the American states and concluded that the individuallevel relationship contributes to but does not explain the entirety of the relationship perceived among states. Multilevel or hierarchical analysis is another statistical tool that allows researchers to assess the relative contributions of individual- and ecologicallevel phenomena for individual-level outcomes such as health. Table II summa- 


\section{TABLE II}

Income Inequality, Individual Income and Health: Multilevel Relationships in the United States

\begin{tabular}{|c|c|c|c|c|}
\hline Author(s) & Context & Health & Income Inequality & Relationship \\
\hline Diez-Roux et al. ${ }^{45}$ & American states $(n=44)$ & $\begin{array}{l}\text { Four cardiovascular } \\
\text { disease factors }\end{array}$ & Robin Hood Index & $\begin{array}{l}\text { For three of four risk factors, inequality } \\
\text { most relevant for low income people. }\end{array}$ \\
\hline Kahn et al. ${ }^{46}$ & American states $(n=50)$ & $\begin{array}{l}\text { Maternal depressive } \\
\text { symptoms and self-rated } \\
\text { health }\end{array}$ & Gini coefficient & $\begin{array}{l}\text { Inequality significant, most pronounced } \\
\text { among low income women. }\end{array}$ \\
\hline Daly et al. ${ }^{41}$ & American states $(n=50)$ & Risk for mortality & $\begin{array}{l}\text { Median share } \\
90: 10 \text { ratio } \\
\text { 80:20 ratio } \\
\text { 90:50 ratio } \\
\text { 80:50 ratio } \\
\text { 50:10 ratio } \\
\text { 50:20 ratio }\end{array}$ & $\begin{array}{l}\text { Risks for mortality were related to } \\
\text { inequality after controlling for individual } \\
\text { factors (and including income) for middle- } \\
\text { income non-elderly only. }\end{array}$ \\
\hline Fiscella and Franks ${ }^{47}$ & $\begin{array}{l}\text { American counties } \\
(\mathrm{n}=105)\end{array}$ & Risk for mortality & Median share & $\begin{array}{l}\text { Inequality not significant after controlling } \\
\text { for individual income. }\end{array}$ \\
\hline Soobader and LeClere ${ }^{48}$ & $\begin{array}{l}\text { American counties } \\
(\mathrm{n}=564)\end{array}$ & $\begin{array}{l}\text { Self-perceived health for } \\
\text { working-aged males }\end{array}$ & Gini Index & Inequality barely significant. \\
\hline Soobader and LeClere ${ }^{48}$ & $\begin{array}{l}\text { American census tracts } \\
(n=3642)\end{array}$ & $\begin{array}{l}\text { Self-perceived health for } \\
\text { working-aged males }\end{array}$ & Gini Index & Inequality not significant. \\
\hline
\end{tabular}

TABLE III

Demographic Characteristics of Sample Communities, British Columbia, Canada

\begin{tabular}{|c|c|c|c|c|c|c|}
\hline & Community & $\begin{array}{c}\text { Age-standardized } \\
\text { Mortality Rate } \\
1994-98\end{array}$ & $\begin{array}{l}50 \% \text { Measure, } \\
\text { Income } \\
\text { Inequality }\end{array}$ & $\begin{array}{c}\text { Mean } \\
\text { Household } \\
\text { Income, } 1996\end{array}$ & $\begin{array}{l}\text { Proportion } \\
\text { Aged } 65 \text { and } \\
\text { Under, } 1996\end{array}$ & $\begin{array}{c}\text { Population, } \\
1996\end{array}$ \\
\hline Northern mainland and & Masset & 96.07 & 26.84 & 50,105 & 96.53 & 1,293 \\
\hline \multirow[t]{2}{*}{ Queen Charlotte Islands } & Prince Rupert & 81.07 & 23.01 & 54,760 & 93.75 & 16,714 \\
\hline & Kitimat & 73.45 & 28.57 & 62,944 & 94.48 & 11,136 \\
\hline \multirow[t]{17}{*}{ Vancouver Island } & Tahsis & 54.71 & 31.66 & 61,341 & 97.34 & 940 \\
\hline & Port McNeil & 62.45 & 26.69 & 63,547 & 97.78 & 2,925 \\
\hline & Port Alice & 42.47 & 31.47 & 65,444 & 96.24 & 1,331 \\
\hline & Port Hardy & 80.06 & 25.80 & 55,708 & 96.69 & 5,283 \\
\hline & Gold River & 106.78 & 35.80 & 67,114 & 98.53 & 2,041 \\
\hline & Ucluelet & 64.73 & 26.51 & 52,374 & 93.67 & 1,658 \\
\hline & Tofino & 76.54 & 24.27 & 49,641 & 94.87 & 1,170 \\
\hline & North Cowichan & 57.05 & 22.31 & 47,830 & 85.62 & 25,305 \\
\hline & Duncan & 117.56 & 24.10 & 32,374 & 73.61 & 4,583 \\
\hline & Ladysmith & 127.90 & 25.20 & 44,853 & 83.42 & 6,456 \\
\hline & Nanaimo & 67.70 & 23.02 & 44,660 & 85.35 & 70,130 \\
\hline & Parksville & 75.41 & 25.69 & 37,749 & 71.81 & 9,472 \\
\hline & Qualicum Beach & 52.03 & 25.21 & 47,801 & 65.53 & 6,728 \\
\hline & Port Alberni & 85.53 & 21.72 & 42,742 & 86.41 & 18,468 \\
\hline & Comox & 74.81 & 27.59 & 50,572 & 85.14 & 11,069 \\
\hline & Courtenay & 71.88 & 23.60 & 39,749 & 86.47 & 17,335 \\
\hline & Campbell River & 74.21 & 23.73 & 50,834 & 90.81 & 28,851 \\
\hline \multirow[t]{4}{*}{ Southern mainland } & Powell River & 71.45 & 22.53 & 46,128 & 83.89 & 13,131 \\
\hline & Gibsons & 127.76 & 21.62 & 41,620 & 80.59 & 3,732 \\
\hline & Sechelt & 81.45 & 24.03 & 44,870 & 78.88 & 7,343 \\
\hline & Squamish & 61.56 & 25.26 & 56,012 & 92.74 & 13,994 \\
\hline Mean & & 78.63 & 25.68 & 50,449 & 87.90 & 11,712 \\
\hline Median & & 74.51 & 25.20 & 49,873 & 88.60 & 7,036 \\
\hline Standard deviation & & 22.47 & 3.43 & 9,087 & 9.02 & 14,669 \\
\hline
\end{tabular}

rizes findings from pertinent multilevel studies in the United States, some of which indicate that income inequality at the level of state is at least weakly related to health after controlling for individual incomes. These findings suggest that while ecological relationships at various levels of analysis in Canada represent a worthwhile pursuit, the intense furor originally surrounding the notion of income inequality as a determinant of population health was possibly premature.

\section{METHODS}

The 24 communities explored herein (Table III) are the incorporated municipalities along the coast of British Columbia, excluding the large urban centres Vancouver and Victoria. All-cause mortality rates were provided by Vital Statistics at the BC Ministry of Health and comprise the crude mortality rate, the mortality rate standardized for age and the age-standardized mortality rates for males and females (over- all and also within three age groups). Because of small population sizes, the mortality rates were averaged over a five-year time period (1994-98) to preserve confidentiality. The economic data were prepared by BCStats and drawn from the 1996 Census and utilized household incomes (although household income does not include all monetary assets and thus likely underestimates total household wealth). Two such measures assessed the degree of skew in the distribution of 
TABLE IV

Correlations Among Measures of Income Inequality and Median Household Income, 1996

\begin{tabular}{|c|c|c|c|c|c|}
\hline Mean-median measure (MM) & $\begin{array}{l}\mathbf{M M} \\
1.0\end{array}$ & SD & $\mathbf{5 0} \%$ & $10 \%$ & MI \\
\hline Standard deviation measure (SD) & $\begin{array}{l}r=0.765, p<0.001 \\
\text { tau=-0.641, } p<0.001\end{array}$ & 1.0 & & & \\
\hline Poorest $50 \%$ measure & $\begin{array}{l}r=-0.690, p<0.001 \\
\text { tau=-0.508, } p<0.001\end{array}$ & $\begin{array}{l}r=-0.754, p<0.001 \\
\text { tau=-0.618, } p<0.001\end{array}$ & 1.0 & & \\
\hline Poorest $10 \%$ measure & $\begin{array}{l}- \\
\operatorname{tau}\end{array}=0.264, p=0.040$ & $\begin{array}{l}- \\
\operatorname{tau}\end{array}=0.145, p=0.261$ & $\begin{array}{l}- \\
\operatorname{tau}=-0.039, p=0.762\end{array}$ & 1.0 & \\
\hline Median household income (MI) & $\begin{array}{l}- \\
\text { tau }=-0.704, p<0.001\end{array}$ & $\begin{array}{l}- \\
\operatorname{tau}=-0.430, p=0.002\end{array}$ & $\begin{array}{l}\mathrm{r}=0.575, \mathrm{p}=0.002 \\
\mathrm{tau}=0.447, \mathrm{p}=0.001\end{array}$ & $\begin{array}{l}\mathrm{r}=-0.450, \mathrm{p}=0.018 \\
\mathrm{tau}=-0.447, \mathrm{p}=0.001\end{array}$ & 1.0 \\
\hline
\end{tabular}

incomes, the first by subtracting the median from the mean household income and dividing by the median, the second by dividing the standard deviation of incomes by the mean household income. The third measure calculated the proportion of total income dollars held by the poorest $50 \%$ of households and the fourth the proportion held by the poorest $10 \%$ of households, each facilitated by assigning the mid-point income of an income category to each household. Pearson's correlation was calculated when the zero-order relationship was linear and sans influential points. Kendall's tau_b, a non-parametric statistic, was calculated when the relationship was nonlinear and/or was adversely affected by influential points. Partial correlations were used for multivariate analysis.

\section{RESULTS}

Table IV describes interrelationships among the four measures of income inequality. The $10 \%$ measure of inequality, an apparently rogue measure, was removed from further consideration. The mean-median, standard deviation and 50\% measures were significantly related to the crude mortality rate in the expected direction $(\mathrm{r}=0.817, \mathrm{p}<0.001 ; \mathrm{r}=0.601, \mathrm{p}=0.002$; $\mathrm{r}=-0.512, \mathrm{p}=0.011$, respectively). These relationships disappeared upon standardizing mortality for age $(r=0.233, p=0.272$; $r=-0.008, p=0.972 ; r=-0.142, p=0.509$, respectively), suggesting that relationships between inequality and crude mortality were spurious, dependent upon the distribution of ages in communities. In an exploratory fashion, distinguishing agestandardized mortality rates for males from females and additionally distinguishing mortality rates within three age categories by gender produced several meaningful relationships. In particular, the agestandardized mortality rate for males aged 0-44 was significantly related to the meanmedian $(\mathrm{r}=0.459, \mathrm{p}=0.024)$ and $50 \%$ $(\mathrm{r}=-0.418, \mathrm{p}=0.042)$ measures of inequality, with some suggestion that the same measures of inequality were also relevant for mortality rates among males aged 45-64 ( $\mathrm{r}=0.392, \mathrm{p}=0.058$; tau_b=-0.275, $\mathrm{p}=0.059$, respectively).

As shown elsewhere, mean household income was a strong correlate of agestandardized mortality among these 24 communities. ${ }^{49}$ Table IV shows strong relationships between both mean and median household income and the three valid measures of income inequality, wherein wealthier communities tended to have more equality, suggesting that even the few meaningful relationships between inequality and mortality just described may simply reflect a community wealth and health relationship. Indeed, mortality rates for males aged $0-44(\mathrm{r}=-0.268, \mathrm{p}=0.216$; $\mathrm{r}=0.101, \mathrm{p}=0.647$ for the mean-median and $50 \%$ measures, respectively) and for males aged 45-64 ( $\mathrm{r}=-0.191, \mathrm{p}=0.383$; $\mathrm{r}=0.114, \mathrm{p}=0.603$ for the mean-median and $50 \%$ measures, respectively) were statistically unrelated to these measures of income inequality after controlling for mean household income.

\section{DISCUSSION}

Income inequality and age-standardized mortality were not significantly related among these coastal communities after controlling for mean household income. Were these non-relationships dependent on an income-health relationship at the individual-level or were positive ecological relationships masked by confounding factors? In the absence of multilevel analysis, we can only speculate when interpreting the results presented in this article.

Toward understanding how the individual-level relationship may be relevant in this instance, two ideal-typical explanations for the income-health relationship can be proffered. The 'materialist' explanation focuses on the absolute purchasing power of income, arguing that income functions to secure material resources (e.g., safe cars, good food and structurally sound houses) and reduce health-damaging exposures that influence health. The 'psychosocial' explanation, on the other hand, focuses on interpretation and perception, arguing that high status people experience less anxiety, engage in more satisfying interactions with others and more successfully exercise power in their interactions. These perceptions and interactions are then presumed to influence peoples' mental and physical health.

For the reasons described in the introduction, given the materialist explanation for the income-health relationship, we would expect to find ecological relationships between both community wealth and income inequality on the one hand and population health on the other, provided there was sufficient variability in the independent and dependent variables. Given the psychosocial explanation, however, we would not predict ecological relationships between community wealth and/or income inequality and aggregate health to hold equally at all levels of analysis. Income relative to others is what matters, and if the entire strata of peers for comparison are represented in each community, then the overall average wealth is irrelevant and the degree of income inequality very relevant for health. The ecological relationship between income inequality and health would not hold, on the other hand, if the 
communities were all subsets of the larger community with whom people generally compare themselves. It seems sensible to assume that Canadians rate their own status in comparison with an encompassing national community rather than exclusively with in-community peers, especially given national and global communications and media. As such the psychosocial explanation, interpreted in this way, represents a viable interpretation for the non-relationship between income inequality and health described among these coastal communities, validated by the lack of compelling relationships between inequality and health elsewhere in Canada. On the other hand, there is a chance that other, unmeasured, ecological correlates have masked a truly ecological relationship between income inequality and mortality. Ross et al. ${ }^{44}$ suggest that the inequality-health relationship may be non-linear, that differences in the distribution of resources such as quality education and health care may influence the (lack of a) relationship, or that there is simply less economic segregation in Canada specific to place than there is in the United States.

As mentioned earlier, the viability of these interpretations can be clarified empirically only through the use of multilevel analysis, thereby enabling distinction between individual- and community-level effects. Such analysis requires the collection of individual-level data nested within communities and additional measurements of relevant ecological characteristics of communities. The non-relationships at the community-level between income inequality and mortality and the strong relationships between various measures of economic prosperity and mortality ${ }^{49}$ in this particular context set the stage for further exploration of the determinants of the health of these populations, pursued in the summer of 2002 via a survey of randomly selected individuals and the collection of community-level data pertaining to social capital, social and economic inequality along social class lines and the nature of economic activity and productivity. The causal pathways by which economic and social inequalities influence population health remain one of the more compelling and interesting issues in Canadian public health research.

\section{REFERENCES}

1. Feinstein JS. The relationship between socioeconomic status and health: A review of the literature. Milbank Q 1993;71:279-322.

2. Adler NE, Boyce T, Chesney MA, Cohen S, Folkman S, Kahn RL, et al. Socioeconomic status and health: The challenge of the gradient. Am Psychologist 1994;49(1):15-24.

3. Charlton BG, White M. Living on the margin: A salugenic model for socio-economic differentials in health. Public Health 1995;109:235-43.

4. Fein $\mathrm{O}$. The influence of social class on health status: American and British research on health inequalities. J General Internal Med 1995;10:57786.

5. James WP, Nelson M, Ralph A, Leather S. Socioeconomic determinants of health. The contribution of nutrition to inequalities in health. BMJ 1997;314:1545-49

6. Macintyre S. The Black Report and beyond: What are the issues? Soc Sci Med 1997;44(6):72345.

7. Rogot E, Sorlie PD, Johnson NJ. Life expectancy by employment status, income, and education in the National Longitudinal Mortality Study. Public Health Rep 1992;107(4):457.

8. Backlund E, Sorlie PD, Johnson NJ. The shape of the relationship between income and mortality in the United States: Evidence from the national longitudinal mortality study. Annals of Epidemiology 1996;6:1-9.

9. Wolfson M, Rowe G, Gentleman JF, Tomiak M. Career earnings and death: A longitudinal analysis of older Canadian men. J Gerontological Soc Sci 1993; 48:167-79.

10. Denton M, Walters V. Gender differences in structural and behavioral determinants of health: An analysis of the social production of health. Soc Sci Med 1999;48:1221-35.

11. Wood E, Sallar AM, Schechter MT, Hogg RS. Social inequalities in male mortality amenable to medical intervention in British Columbia. Soc Sci Med 1999;48:1751-58.

12. Humphries KH, van Doorslaer E. Income-related health inequality in Canada. Soc Sci Med 2000;50:663-71.

13. Veenstra G. Social capital, SES and health: An individual-level analysis. Soc Sci Med 2000;50:619-29.

14. Raphael D. From increasing poverty to societal distintegration: How economic inequality affects the health of individuals and communities. In: Armstrong P, Armstrong H, Coburn D (Eds.), Unhealthy Times: Political Economy Perspectives on Health and Care in Canada. Oxford University Press, 2001.

15. Wolfson M, Kaplan G, Lynch J, Ross N, Backlund E. The relationship between income inequality and mortality: An empirical demonstration. BMJ 1999;319:953-57.

16. Judge K, Mulligan J-A, Benzeval M. Income inequality and population health. Soc Sci Med 1998;46(4-5):567-79.

17. Ecob R, Davey Smith G. Income and health: What is the nature of the relationship? Soc Sci Med 1999;48:693-705.

18. Lynch J, Kaplan GA. Understanding how inequality in the distribution of income affects health. J Health Psychol 1997;2(3):297-314.

19. Kawachi I, Kennedy BP, Wilkinson R. Crime: Social disorganization and relative deprivation. Soc Sci Med 1999;48:719-31.

20. Muntaner C, Lynch J. Income inequality, social cohesion, and class relations: A critique of Wilkinson's neo-Durkheimian research program. Int J Health Services 1999;29(1):59-81.

21. Coburn D. Income inequality, social cohesion and the health status of populations: The role of neo-liberalism. Soc Sci Med 2000;51:135-46.
22. Wilkinson R. Income inequality, social cohesion, and health: Clarifying the theory - A reply to Muntaner and Lynch. Int I Health Services 1999;29(3):525-43.

23. Wilkinson RG. Unhealthy Societies: The Afflictions of Inequality. London: Routledge, 1996

24. Kawachi I, Kennedy B, Lochner K, Prothrow-Stith D. Social capital, income inequality, and mortality. Am J Public Health 1997;87(9):1491-98.

25. Veenstra G. Social capital and health. ISUMA: Can J Policy Research 2001;2(1):72-81.

26. Veenstra G. Social capital and health (plus wealth, income inequality and regional health governance). Soc Sci Med 2002;54:849-68.

27. Gravelle H. How much of the relation between population mortality and unequal distribution of income is a statistical artefact? $B M J$ 1998;316(7128):382

28. Lynch J, Davey Smith G, Hillemeier M, Shaw M, Raghunathan T, Kaplan G. Income inequality, the psycho-social environment and health: Comparisons of wealthy nations. Lancet 2001;358(9277):194-200.

29. Rodgers GB. Income and inequality as determinants of mortality: An international cross-section analysis. Population Studies 1979;33(2):343-51.

30. Flegg AT. Inequality of income, illiteracy and medical care as determinants of infant mortality in underdeveloped countries. Population Studies 1982;36(3):441-58.

31. Le Grand J. Inequalities in Health: Some International Comparisons. European Economic Review 1987;31:182-91.

32. Waldmann RJ. Income distribution and infant mortality. QJ Economics 1992;Nov:1283-302

33. Wilkinson RG. Income distribution and life expectancy. BMJ 1992;304:165-68.

34. Wennemo I. Infant mortality, public policy and inequality - A comparison of 18 industrialised countries 1950-85. Sociology of Health \& Illness 1993;15(4):429-46.

35. Duleep HO. Mortality and income inequality among economically developed countries. Soc Security Bull 1995;58:34-50.

36. Steckel R. Stature and the standard of living. J Economic Literature 1995;XXXIII:1903-40.

37. Judge K. Income distribution and life expectancy: A critical appraisal. BMJ 1995;311:1282-85.

38. Pampel FC, Jr., Pillai VK. Patterns and determinants of infant mortality in developed nations, 1950-1975. Demography 1986;23(4):525-42.

39. Saunders P. Poverty, Income Distribution and Health: An Australian study. No. 128, Reports and Proceedings, Social Policy Research Centre, University of New South Wales, 1996.

40. Kawachi I, Kennedy BP. The relationship of income inequality to mortality: Does the choice of indicator matter? Soc Sci Med 1997;45(7):1121-27.

41. Daly MC, Duncan GJ, Kaplan GA, Lynch JW. Macro-to-micro links in the relation between income inequality and mortality. The Milbank $Q$ 1998;76(3):315-39.

42. Lynch JW, Kaplan GA, Pamuk ER, Cohen RD, Heck KE, Balfour JL, et al. Income inequality and mortality in metropolitan areas of the United States. Am J Public Health 1998;88(7):1074-79.

43. Wilson M, Daly M. Life expectancy, economic inequality, homicide, and reproductive timing in Chicago neighbourhoods. BMJ 1997;314(7089): 1271.

44. Ross NA, Wolfson MC, Dunn JR, Berthelot JM, Kaplan GA, Lynch JW. Relation between income inequality and mortality in Canada and in the United States: Cross sectional assessment using census data and vital statistics. BMJ 2000;320(April):898-902.

45. Diez-Roux AV, Link BG, Northridge ME. A multilevel analysis of income inequality and cardiovascular disease risk factors. Soc Sci Med 2000;50:673-87. 
46. Kahn RS, Wise PH, Kennedy BP, Kawachi I. State income inequality, household income, and maternal mental and physical health: Cross sectional national survey. BMJ 2000;321:1311-15.

47. Fiscella K, Franks P. Poverty or income inequality as predictor of mortality: Longitudinal cohort study. BMJ 1997;314:1724-28.

48. Soobader M-J, LeClere FB. Aggregation and the measurement of income inequality: Effects on morbidity. Soc Sci Med 1999;48:733-44.

49. Veenstra G. Economy, community and mortality in British Columbia, Canada. Soc Sci Med, in press.

Received: August 7, 2001

Accepted: May 21, 2002

\section{RESUME}

Objectif : La répartition inégale des ressources économiques (c.-à-d. I'inégalité des revenus) dans une collectivité est une caractéristique susceptible d'influencer la santé générale de la population. L'inégalité des revenus semble fortement associée aux taux de mortalité dans les collectivités comme les États et les zones métropolitaines aux États-Unis, mais au Canada, elle ne semble pas jouer sur l'état de santé dans les ensembles géopolitiques semblables. Nous faisons ici la synthèse des preuves pertinentes, en Amérique du Nord et dans le reste du monde, et nous étudions les liens entre l'inégalité des revenus et les taux de mortalité dans les collectivités côtières de la province canadienne de la Colombie-Britannique.

Méthode : Nous avons fait l'analyse transversale de 24 collectivités côtières de la ColombieBritannique à l'aide de quatre indicateurs du recensement de 1996 afin de mesurer l'inégalité des revenus et les taux bruts de mortalité, sans strate d'âges, puis avec strates d'âges et de sexe. Nous avons fait la moyenne de ces taux sur cinq ans (1994-1998) pour mesurer l'état de santé.

Résultats : Les trois indicateurs valides d'inégalité des revenus étaient associés de façon positive et significative au taux brut de mortalité, mais non au taux de mortalité sans strate d'âges. Deux des indicateurs étaient associés aux taux de mortalité des hommes de 0 à 44 ans et de 45 à 64 ans avant rectification en fonction du revenu des ménages, mais ils ne l'étaient plus après.

Conclusion : Les chercheurs médicaux n'ont pas encore découvert de lien significatif entre I'inégalité des revenus et la santé de la population au Canada. Au risque d'être accusé de sophisme écologique, nous pensons que ces résultats appuient provisoirement une interprétation psychosociale du lien individuel entre le revenu et la santé, à savoir que les membres des collectivités en question se comparent à un ensemble global (p. ex., à tous les Canadiens).

\section{Directives de rédaction de la RCSP}

La Revue canadienne de santé publique publie des articles originaux sur tous les aspects de la santé publique, de la médecine préventive et de la promotion de la santé qui ont été évalués par des pairs. Tous les manuscrits soumis pour publication dans ses colonnes doivent respecter les Directives de rédaction de la RCSP. On trouvera une version complète sur le site Web de l'ACSP à l'adresse suivante < www.cpha.ca/francais/cjph/stylreq/ style.htm >. Les auteurs qui n'ont pas accès à Internet peuvent se reporter aux pages 7-8 du numéro de janvier/février 2002 (Vol. 93, No. 1) de la Revue canadienne de santé publique ou se mettre en rapport avec le bureau de la rédaction pour en recevoir un exemplaire par télécopieur.

La Rédaction doit recevoir un exemplaire imprimé de l'original et deux copies pour l'évaluation par les pairs (dactylographié à double interligne, sur un seul côté de la feuille) avec toutes les figures et tous les tableaux, et accompagné d'une version électronique. Veuillez numéroter les pages les unes à la suite des autres, y compris le résumé et sa traduction (le cas échéant), le texte, les remerciements, les références, les tableaux et les figures.

Les articles originaux ne doivent pas dépasser 2000 mots. Veuillez indiquer le nombre de mots de votre article. Les brefs comptes-rendus peuvent être soumis et doivent inclure des résumés structurés (voir le paragraphe "Les documents sont...»)

La Revue a adopté une politique d'évaluation des articles par des pairs, en double aveugle. Auteurs et évaluateurs restent anonymes. Afin d'assurer l'anonymat de cette évaluation par des pairs, les auteurs doivent s'assurer de ne donner les renseignements les identifiant que sur la page titre de l'original seulement; seul le titre doit apparaître sur les deux copies à l'intention des évaluateurs.
La page titre de l'original doit comporter : 1) le titre; 2) un bref sous-titre de 40 caractères au maximum (y compris les blancs); 3) les noms, prénoms et initiales du milieu (le cas échéant) des auteurs, accompagnés de leurs diplômes d'études de plus haut niveau avec les noms du service et de l'organisme dans le cadre duquel le travail publié a été effectué; 4) le nom, l'adresse, le numéro de téléphone, le numéro de télécopieur et l'adresse électronique de l'auteur à qui adresser toute correspondance; 5) le nom et l'adresse de l'auteur à qui les demandes de réimpression doivent être envoyées (s'il s'agit de la même personne, regroupez 4 et 5 ensemble).

Les déclarations relatives aux limites de responsabilité et les mentions concernant l'aide reçue doivent aussi figurer sur la page titre. Une lettre signée par tous les auteurs comme quoi ils acceptent d'être publiés doit être incluse.

Les documents sont acceptés en anglais ou en français. La page deux doit présenter un résumé structuré pouvant avoir jusqu'à 250 mots, avec les titres : Objectif, Méthodes, Résultats, Discussion (ou Interprétation). En outre, la RCSP demande une traduction professionnelle du résumé. Pour garantir une qualité constante de la traduction de la Revue, la RCSP se réserve le droit de faire retraduire les résumés soumis, aux frais des auteurs après les en avoir avisés. S'ils le préferent, les auteurs peuvent demander de faire traduire directement leurs résumés par le traducteur officiel de la Revue à raison de 22 cents le mot plus la TPS de 7 \% (ou le TVH de $15 \%$ ).

Nous vous encourageons à écrire à la Rédaction, en vous priant d'envoyer des lettres aussi courtes que possible.

La Rédaction se réserve le droit de modifier les articles.

Les documents à publier doivent être soumis au rédacteur scientifique de la Revue canadienne de santé publique, 1565 avenue Carling, bureau 400, Ottawa, Ontario (Canada) K1Z 8R1. 